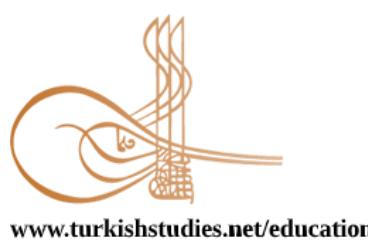

www.turkishstudies.net/education
Turkish Studies - Educational Sciences

eISSN: 2667-5609

Research Article / Araștırma Makalesi

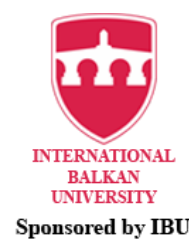

Sponsored by IBU

\title{
Öğretmen Eğitimi Kalite Geliştirme Çalışması: CAEP ve Teknoloji Entegrasyonu*
}

\author{
A Study of Enhancing Quality of Teacher Education: Council for the Accreditation of Educator \\ Preparation and Technology Integration
}

\author{
Nazire Burçin Hamutoğlu** - Şule Yılmaz Özden ${ }^{* * *}-$ Muzaffer Elmas****
}

\begin{abstract}
Teacher training policies are on the agenda of most of the developed countries. The fact that the issues related to teacher education are at the top of the agenda at the global level gives an international impetus to the studies related to improving the quality of teacher education. Council for the Accreditation of Educator Preparation (CAEP) is one of the most important accreditation institutions that work on this level at the global level. Accordingly, taking into consideration of the CAEP, which has a strong and rich accreditation history of teacher education programs, in this study, it is aimed to examine the accreditation efforts aimed at improving the quality of teacher education programs in Turkey. This study explores the following questions: 1 . What is the purpose of CAEP? 2. How is the CAEP accreditation process? 3. What are the standards of CAEP? 4. What is the place of technology integration in the CAEP accreditation process? 5. What are the institutions accredited by CAEP outside of the United States of America (USA)? What is the importance of these institutions in terms of education? 6. Why is the accreditation of teacher training institutions in Turkey important? In light of these questions, this study provides recommendations to improve the quality of teacher training programs in Turkey.
\end{abstract}

Structured Abstract: Introduction: Teacher training policies are on the agenda of most of the developed countries. The fact that the issues related to teacher education are at the top of the agenda at the global level gives an international impetus to the studies related to improving the quality of teacher education. Council for the Accreditation of Educator Preparation (CAEP) is one of the most important accreditation institutions that work on this level at the global level.

\footnotetext{
* Bu çalışmanın bir bölümü International Conference on Quality in Higher Education (ICQH)-2019'da sözlü bildiri (özet) olarak sunulmuştur/One part of this study was presented at International Conference on Quality in Higher Education (ICQH)-2019 as an oral paper.

** Dr., Eskişehir Teknik Üniversitesi, Öğrenme ve Öğretme Gelişimi Birimi

Dr., Eskisehir Technical University, Rector's Office

ORCID 0000-0003-0941-9070

nbhamutoglu@eskiehir.edu.tr

**** Dr., Sakarya University, Eğitim Fakültesi, Bilgisayar ve Öğretim Teknolojileri Eğitimi Bölümü

Dr., Sakarya University, Faculty of Education, Department of Computer and Education Technologies Education

ORCID 0000000307257338

sule@sakarya.edu.tr

**** Prof., Dr., Türkiye Cumhuriyeti Yükseköğretim Kalite Kurulu

Prof., Dr., Turkish Higher Education Quality Council

ORCID 0000-0003-3202-6689

elmas@yokak.gov.tr

Cite as/ Atıf: Hamutoğlu, N. B. \& Yılmaz Özden, Ş. \& Elmas, M. (2020). Öğretmen eğitimi kalite geliştirme çalışması: CAEP ve teknoloji entegrasyonu. Turkish Studies - Education, 15(4), 2671-2690. https://dx.doi.org/10.47423/TurkishStudies.44403

Received/Geliş: 22 June/Haziran 2020

Accepted/Kabul: 27 August/Ağustos 2020

Copyright (C INTAC LTD, Turkey 


\section{The significance of the study}

It is important that education faculties are accredited in terms of globalization and quality. Continuous improvements and sustainable innovations to achieve the accreditation standards will lead to implement the necessary reforms in order to achieve the desired outcome in education faculties. Increasing the quality of teacher education programs in order to ensure that teachers are more qualified and sufficient digital literacy skills is very important in terms of training teachers who can integrate technology into learning-teaching processes with appropriate pedagogical methods and are equipped with other skills required by the 21 st century.

According to the report prepared by the American Association of Colleges for Teacher Education (AACTE) and the 21st Century Skills Partnership (Partnership for 21st Century Skills [P21]), teachers should have proficiency in how to develop and use a program for the 21 st century skills; however, this requires an approach that goes far beyond adding an additional lesson or lesson hours (Greenhill, 2010). It is believed that this approach can be achieved through an effective accreditation process. According to Midraj and Harold (2016), accreditation is a proof that teacher training programs have achieved important international professional standards to prepare teachers for future educational settings. From this point of view, it is very important to prove the compatibility of practices of teacher training programs with professional standards for globalization. Although there are some attempts by institutions to present the quality of their programs by national accreditation institutions, it is important to address these initiatives at a global level. Based on the definition of globalization creating mass demand in higher education (Altbach, 2005), practices of teacher training programs should be brought to the international level. Therefore, it is important to achieve international accreditation in order to enable academic institutions to compete at global level.

\section{Purpose}

Accordingly, taking into consideration of the CAEP, which has a strong and rich accreditation history of teacher education programs, in this study, it is aimed to examine the accreditation efforts aimed at improving the quality of teacher education programs in Turkey. This study explores the following questions:

Q1. What is the purpose of CAEP?

Q2. How is the CAEP accreditation process?

Q3. What are the standards of CAEP?

Q4. What is the place of technology integration in the CAEP accreditation process?

Q5. What are the institutions accredited by CAEP outside of the United State of America (USA)? What is the importance of these institutions in terms of education?

Q6. Why is the accreditation of teacher training institutions in Turkey important?

In light of these questions, this study provides recommendations to improve the quality of teacher training programs in Turkey.

\section{Method}

In the study, CAEP's Accredited and Provider Search Page (CAEP, 2020b) was scanned and the institutions accredited by CAEP were contacted via e-mail. Richness of the data was provided in accordance with the objectives of the study.

There are three universities currently accredited by CAEP outside of the United States: Sultan Qaboos University in Umman, Qatar University in Qatar, and Zayed University in the United Arab Emirates. In this study, only the information regarding the accreditation process of Qatar University was introduced since we were able to obtain rich information about the accreditation process and technology integration practices through this process.

\section{Findings (Results)}

When we investigate the institutions accredited by CAEP outside of the USA, it is noteworthy that all of these institutions are from Arabic countries. CAEP is a highly recognized and reliable institution for the accreditation of teacher training programs worldwide. Therefore, it is surprising that there are no other educator preparation institutions from non-Arabic countries throughout the world accredited by CAEP. Although the 
reasons for this situation are out of the aims of this study, it is thought that socio-economic situations, long and costly accreditation process and the existence of different national and international accreditation institutions might be the reason. In addition, it is also envisioned that a variety of institutions from various countries have applied to CAEP for an accreditation but the process has not been completed yet (CAEP, 2020b).

Qatar University's management approach is based on a monarchical order which considered as the reason for the rapid reform in education system in Katar. However, this monarchical system is unacceptable in terms of governance and policies of the Republic of Turkey. However, Qatar University sets an example in terms of reforms in their educational system both in general and in teacher education programs in order to accredited by CAEP. In teacher education, it may be possible to evaluate these practices regarding quality in teacher education by taking into account the cultural context and values of Turkey.

Altbach (2005) states that by taking advantage of globalization to make the best use of this century's world, it has the dynamics that allow countries and academic systems to develop and implement policies. When it comes to quality of teacher training, it is suggested that the arrangements made in these countries can be taken as an example in the regulations to be made and implemented on the basis of democratic and pluralistic management understanding and order of Turkey. In addition, considering the practices of these institutions regarding how to integrate technology into teacher training programs, necessary adaptation and adjustments can be carried out and focused in line with the competencies and abilities of our country's higher education institutions. Finally, future research can explore the institutions in European Union that provide accreditation in the field of teacher training.

Keywords: CAEP, Teacher Training, Accreditation, Higher Education, Quality, Turkey.

Öz: Öğretmen yetiştirme politikaları, gelişmiş ülkelerin gündeminde öncelikli olarak yer almaktadır. Öğretmen eğitimi ile ilgili konuların küresel düzeyde gündemin en üst sıralarında yer alması, öğretmen eğitiminin kalitesini arttırma ile ilgili çalışmalara uluslararası yönde bir ivme kazandırmaktadır. Eğitimci Yetiştirme Akreditasyon Konseyi (CAEP-Council for the Accreditation of Educator Preparation) bu alanda, küresel düzeyde çalışmalarını gerçekleştirmekte olan en önemli akreditasyon kurumlarından birisidir. Buna göre, öğretmen ve eğitimci yetiştirme üzerine güçlü ve zengin bir akreditasyon geçmişi olan CAEP'in yaptığ 1 çalışmalar dikkate alınarak, bu çalışmada ülkemiz yükseköğretim kurumlarının öğretmen yetiştirme kurumları olan eğitim fakültelerinde öğretmen eğitimi kalitesini artırmaya yönelik yapılan akreditasyon çalışmalarının nasıl geliştirilebileceğinin araştırılması amaçlanmaktadır. Bu amaç kapsamında (1) CAEP'in amacı nedir? (2) CAEP akreditasyon süreci nasıldır? (3) CAEP'in standartları ve başvuru şartları nelerdir? (4) Teknoloji entegrasyonunun CAEP akreditasyon sürecindeki yeri nedir? (5) Dünya'da, Amerika Birleşik Devletleri (ABD) dışında, CAEP tarafindan akredite edilmiş kurumlar nelerdir? Bu kurumların eğitim açısından önemi nedir? ve (6) Ülkemiz öğretmen yetiştirme kurumlarının akreditasyonu niçin önemlidir? sorularına yanıt aranmaktadır. Çalışma derleme çalışmasına örnektir. Çalışmada ABD dışındaki ülkeler için CAEP'in akredite olan kurumları yayınladığı ilgili web sayfasından tarama yapılmış ve elde edilen veriler doğrultusunda ilgili kurumlar ile e-posta aracılığıyla iletişime geçilerek çalışmanın amaçlarına uygun olacak şekilde veri zenginliği sağlanmıştır. Çalışmada elde edilen veriler doğrultusunda ülkemizde yükseköğretimde öğretmen eğitimine yönelik yapılan uygulamaları geliştirmeye yönelik öneriler sunulmaktadır.

Anahtar Kelimeler: Akreditasyon, CAEP, Kalite, Öğretmen Eğitimi, Yükseköğretim, Türkiye.

\section{Giriş}

Dünyada öğretmen yetiştirme politikaları, gelişmiş ülkelerin aynı fikirde ele aldıkları önem arz eden konuların başında yer almaktadır (European Commission, 2013; Federation of Teachers, 2016). Ekonomik Kalkınma ve İşbirliği Örgütü (Organisation for Economic Co-operation and Development - OECD, 2016) raporunda, öğretmen eğitimi ile ilgili konuların gündemin en üst sıralarında yer aldığı görülmektedir. Söz konusu öğretmen eğitiminin küresel düzeyde önemi göz önüne alındığında, Eğitimci Yetiştirme Akreditasyon Konseyi'nin (CAEP-Council for the Accreditation of Educator Preparation) öğretmen eğitiminin kalitesini artırma ve yeni ilişkiler geliştirme alanındaki kalite çalışmalarını küresel düzeyde gerçekleştirdiği görülmektedir (Bakioğlu, 
2017). CAEP, 2010 yilında ABD'de iki eski akreditasyon kurumu olan 1954'te kurulan National Council for Accreditation of Teacher Education (NCATE) ve 1997'de kurulan Teacher Education Accreditation Council (TEAC) kuruluşlarının birleşmesiyle örnek bir birleşik akreditasyon sistemi oluşturmak için kurulmuştur (CAEP, 2020a). Bununla birlikte CAEP, öğretmen ve eğitimci yetiştirme üzerine güçlü ve zengin bir akreditasyon geçmişi üzerine oturmuş bir konseydir (CAEP, 2020a).

$\mathrm{Bu}$ çalışmanın konusunu öğretmen ve eğitimci yetiştirme üzerine güçlü ve zengin bir akreditasyon geçmişi olan CAEP'in yaptığı çalışmaların dikkate alınması ve bu bağlamda dünyada öğretmen eğitimi kalitesini artırmaya yönelik gerçekleştirilen uygulamalar oluşturmaktadır. $\mathrm{Bu}$ doğrultuda, çalışmada yükseköğretim kurumlarının öğretmen yetiştirme kurumları olan eğitim fakültelerinin öğretmen eğitimi kalitesini artırmaya yönelik yapılan akreditasyon çalışmalarının nasıl geliştirilebileceğinin araştırılması amaçlanmaktadır. Bu amaç kapsamında (1) CAEP'in amacı nedir (2) CAEP akreditasyon süreci nasıldır? (3) CAEP'in standartları ve başvuru şartları nelerdir? (4) Teknoloji entegrasyonu bu akreditasyon biriminin neresindedir? (5) Dünya'da ABD dişında, CAEP tarafından akredite edilmiş kurumlar nelerdir? Bu kurumların eğitim açısından önemi nedir? ve (6) Ülkemiz öğretmen yetiştirme kurumlarının akreditasyonu niçin önemlidir? sorularına yanıt aranmaktadır. Çalışmada elde edilen yanıtlar doğrultusunda ülkemizde yükseköğretimde öğretmen eğitimine yönelik yapılan uygulamaları geliştirmeye yönelik öneriler sunulmaktadır.

\section{Çalışmanın Önemi}

Öğretmen yetiştirme kurumlarının öğretmen eğitimi kalitesini arttırmayı amaçlayan bu çalışma uluslararasılaşma ve küreselleşme temelinde önem arz etmektedir. Erkutlu ve Eryiğit (2001) 'e göre uluslararasılaşma, işletmelerin ulusal faaliyetlerini ulus sınırları dışına yansıması olarak ifade edilmektedir. Yükseköğretimde uluslararasılaşma ise akademik kurumların hatta bireylerin küresel akademik çevrede rekabet edebilmek amacıyla politikalar ve uygulamalar geliştirmesi olarak tanımlanmaktadır (Altbach \& Knight, 2007) ki bu kavram, yükseköğretim kurumlarının sahip olduğu misyon ve vizyon anlayışında neredeyse zorunlu stratejileri arasında yer almaktadır. Bu noktada uluslararasılaşma kavramı küreselleşme kavramından farklılaşmaktadır. Öyle ki yükseköğretimde uluslararasılaşma kavramı iletişim ve kültürler arası geçiş üzerinde yoğunlaşarak; yükseköğretimde kitlesel talebi oluşturan küreselleşme kavramından çok daha güçlüdür (Altbach, 2005). Ayrıca uluslararasılaşma kavramı yeni dünyadan en iyi şekilde faydalanmayı firsat bilerek ülkelerin ve akademik sistemlerin politikalar geliştirmesine ve uygulamasına olanak veren dinamikleri de içerisinde barındırmaktadır (Altbach, 2005). Buna göre, bilgi ve iletişim teknolojilerinde yaşanan gelişmelerin Marshall McLuhan'ın "global village/küresel köy” tanımlamasını çağrıştırdığı ve içinde bulunduğumuz çağda bireylerin dünya ile iletişimde kalarak sürekli bir şekilde benzer duyuları paylaştığı dünyanın küresel bir köy haline geldiğinin altı çizilmektedir (Rigel vd., 2003, Akt. Çiçek, 2016). Bu paylaşımların yalnızca bireyleri değil kurumları da yakından ilgilendirdiği söylenebilir ki yükseköğretim kurumları dünyada ilerleme ve gelişmelerin kaydedildiği önde gelen bilim ortamlarıdır. Buna göre, yükseköğretim kurumları dünyada meydana gelen gelişmelerin bir alıcısı olmakta ve dünya ile benzer duyuları paylaşmaktadır. $\mathrm{Bu}$ nedenledir ki öğretmen eğitiminin dünyanın gelişmiş ülkeleri tarafından gündemde olması bu alanda gerçekleştirilen faaliyetleri uluslararası düzeye taşımayı gerektirmektedir. Amerikan yükseköğretimi dünyanın önde gelen standartlarını ortaya koymaktadır ve bu nedenle de Amerikan akreditasyon sistemini anlama ve bu akreditasyonu elde etme konusunda büyük bir ilgi vardır (Altbach, 2003). Dünyada öğretmen eğitiminde öncü akreditasyon kurumu olan CAEP'in amacının ve öğretmen eğitiminde akreditasyon sürecine ilişkin standartlarının dikkate alınmasının öğretmen eğitiminde kaliteyi artıran bir unsur olmakla birlikte uluslararasılaşma yolunda atılacak önemli bir adım olduğu düşünülmektedir. Bu nedenle bu çalışmada ele alınan araştırma soruları ülkemizde öğretmen eğitimi konusunda yapılacak çalışmaları geliştirme noktasında önemli görülmektedir. Ayrıca içinde bulunduğumuz teknoloji çağında CAEP'in öğretmen yetiştirmeyi esas alan uygulamalarına yönelik yapılan teknoloji 
entegrasyon çalışmalarının da öğretmen eğitiminde kaliteyi destekleyen ve geliştiren çalışmalara yol göstereceği düşünülmektedir.

\section{Yöntem}

$\mathrm{Bu}$ derleme çalışmasında CAEP akreditasyonu alan ABD dışındaki ülkelerde öğretmen yetiştiren programlar, CAEP'in akredite olan kurumları yayınladığı ilgili web sayfasının taraması sonucunda elde edilmiştir (CAEP, 2020b). Bu tarama sonucunda CAEP akreditasyonu alan ABD dışındaki üç farklı ülkedeki eğitim kurumuna ulaşılmıştır. Bu eğitim kurumları, Umman'da Sultan Qaboos Üniversitesi, Katar'da Qatar Üniversitesi ve Birleşik Arap Emirlikleri'nde Zayed Üniversitesi'dir. Daha sonra çalışmanın amaçlarına uygun olarak belirtilen üç kurumun akreditasyon süreci ve teknoloji entegrasyonu ile ilgili bilgi almak ve veri zenginliği sağlamak açısından, kurumlarda akreditasyon ile ilgili yetkili kişilerle e-posta aracılığıyla iletişime geçilmiştir. Ancak ilgili üç kurumdan sadece Qatar Üniversitesi ile iletişim kurulabilmiştir. Bu iletişim sonucunda akreditasyon süreci ve teknoloji entegrasyonu ile ilgili ayrıntılı bilgilere ulaşıldığ gerekçesiyle çalışmaya sadece Qatar Üniversitesi'nin akreditasyon sürecine ilişkin bulgular dahil edilmiştir.

\section{CAEP'in Amacı}

Eğitimci Yetiştirme Akreditasyon Konseyi (Council for the Accreditation of Educator Preparation- CAEP), 2010 yılında ABD'de iki eski akreditasyon kurumu olan 1954'te kurulan Ulusal Öğretmen Eğitimi Akreditasyon Konseyi (National Council for Accreditation of Teacher EducationNCATE) ve 1997'de kurulan Öğretmen Eğitimi Akreditasyon Konseyi (Teacher Education Accreditation Council-TEAC) kuruluşlarının birleşmesiyle örnek bir birleşik akreditasyon sistemi oluşturmak için kurulmuştur (CAEP, 2020a). CAEP, öğretmen ve eğitimci yetiştirme üzerine güçlü ve zengin bir akreditasyon geçmişi üzerine oturmuş bir konseydir (CAEP, 2020a). CAEP şu anda akreditasyon sistemine katılan 900'den fazla eğitimci hazırlık kuruluşu ile birlikte çalışmaktadır. CAEP'in çalışmalarının kapsamı, ABD'nin ve uluslararası öğretmen yetiştirme programlarının sertifika, lisans, yüksek lisans, doktora ve doktora sonrası seviyelerini içermektedir. CAEP'in misyonu, kaliteyi güvence altına alan ve sürekli iyileştirmeyi destekleyen kanıta dayalı akreditasyon yoluyla öğretmen yetiştirmede mükemmelliği arttırmaktır (CAEP, 2020a). CAEP, gözden geçirme prosedürlerini yeniden tasarlamış ve sürekli iyileştirme ve yeniliğe odaklanan kalite güvence sistemlerinin ne kadar sağlıklı çalışı ı̆ını araştıran, sonuç ve kanıtlarla bilgilendirilen bir akreditasyon süreci ortaya koymuştur. Bu yeniden tasarımın nihai amacı, tüm K-12 öğrencileri için öğrenmeyi geliştirmektir (CAEP, 2020a).

Eğitimciler, daha zorlu akademik standartlarla karşı karşıya kalan ve gittikçe çeşitlenen öğrenci popülasyonuna yönelik öğretimin etkinliğinde, çarpıcı gelişmelere yol açmak için okullarda büyük sistemik değişiklikler meydana getirmelidir (CAEP, 2020a). Politikacıların, öğretmen sendikalarının, velilerin ve halkın, öğretmen yetiştirme programlarının eğitim işgücünün değişen ihtiyaçlarını daha etkin bir şekilde karşılaması ve yeni öğretmenlerin yeni zorluklarla başa çıkmak için tam olarak hazır olmaları konusunda büyük endişeleri ve beklentileri bulunmaktadır (CAEP, 2020a). Bu endişeler ve taleplere cevap verebilmek adına CAEP aşağıdaki beş maddeyi temel alarak öğretmen yetiştirme programlarının beklenen kaliteyi yakalamak adına değişimlerini gerçekleştirmeyi amaçlamıştır (CAEP, 2020a).

1. CAEP, yerel veya ulusal düzeyde işverenlerin acil ihtiyaçlarını karşılayacak şekilde K-12 okullarının bulundukları bölgedeki ilgili yerel kurumlarla işbirliği içinde etkili bir hazırlık yapıldığının kanıtlanmasını zorunlu tutmuştur. (Eğitim konusunda sıkıntılı bölgeleri ele almak ve çalışmanın zor olduğu okullara kaliteli öğretmenler yerleştirmek gibi).

2. CAEP, yetenekli, farklı kültür ve sosyo-ekonomik geçmişe sahip adayların programa seçimini ve kaliteli öğretmen adaylarının işe alımı ve öğretmen olmalarının sağlanmasını istemektedir. 
3. CAEP akreditasyonu, tüm öğretmen yetiştirme programlarını içermekte ve üniversiteye dayalı, alternatif, kâr amacı gütmeyen kuruluşlar ve çevrimiçi sağlayıcıların yenilenmesini teşvik etmektedir.

4. CAEP, öğretmenlerin K-12 öğrencilerinin öğrenmesi ve gelişimi üzerindeki etkisinin ögretmen yetiştirme programlarının etkinliğinin nihai testi olduğunu savunmaktadır.

5. CAEP, öğretmen yetiştirme programlarının sürekli gelişmeleri için kapasitelerini verilere dayalı olarak artırmalarını teşvik etmekte ve yardımcı olmaktadır. Bu, tüm öğretmen yetiştirme programları arasında akreditasyonun uygunluğunu ve etkisini artıran önemli ve kilit bir sonuçtur.

CAEP, tüm öğretmen yetiştirme programlarını yaptıkları çalışmalar hakkında bilgilendirmek için bir belgeleme kültürü oluşturmaya çağırmaktadır (CAEP, 2020a). Böyle bir kültür, veri toplama ve izlemeyi, uygun paydaşların katılımını ve geri bildirimlerini, nicel ve nitel ölçüm sonuçlarına odaklanmayı ve öğretmen yetiştirme programlarının etkinliğini artırmak için kanıt kullanmayı destekleyen bir altyapı üzerine kuruludur (CAEP, 2020a). Bu durum eğitim fakültelerinin, 2013 CAEP standartlarını sağlayabilmesi için uygun kanıtları kullanıp, kalitesi hakkında mevcut kanıtları yorumlamasını gerektirmektedir. Ayrıca, bu programlar, mevcut kanıtların kalitesini iyileştirerek destekleyecek olup; diğer kanıt kaynaklarının araştırılıp keşfedilmesine olanak sağlamaktadır.

Öğretmen adaylarının, öğretmen yetiştirme programlarının ve fakültelerinin performansını belgeleyen daha fazla ve daha yüksek kalitede verilerin bulunması, öğretmen yetiştirme programlarının kamuya karşı hesap verebilirlik konusundaki sorumluluklarını yerine getirmeleri ve öğretmen yetiştirme konusunda sürekli iyileştirmeleri teşvik etmeleri için eşsiz bir firsat sunmaktadır.

\section{CAEP ve Akreditasyon Süreci}

CAEP'in 2013'te yayınlanan kılavuz kitapçığında belirtildiği üzere, akreditasyon sürecinin bir parçası olarak, eğitim fakülteleri akreditasyon alma veya sürdürme arayışlarında izleyecekleri üç CAEP akreditasyon yolundan birini seçmektedir. CAEP akreditasyonu için üç yol; özet sorgulama, seçilmiş iyileştirme ve dönüşüm girişimi'dir. CAEP standartlarını karşılamak için eğitim fakültelerinin yapması gereken faaliyetler bu üç yol için de aynı olmasına rağmen, bu üç yolun farklı odak noktaları olup, sürekli iyileştirmeyi nasıl sağlayacakları konusunda farklılıklar mevcuttur.

$\mathrm{Bu}$ üç yoldan birincisi, özet sorgulama yolu öğretmen adaylarının ve mezunların çıktıları üzerinde çalışılmasına odaklanmaktadır. Bu yol, eğitim fakültesinin ve içerisindeki programların misyonları ve çıktıları hakkındaki sorulara cevap ile başlayan sorgulamaya dayanan bir süreçtir. $\mathrm{Bu}$ süreçte, fakülte, tüm 2013 CAEP standartlarının karşılandığını belgelemektedir. Seçilmiş iyileştirme yolu ise, eğitim fakültelerinin, öğretmen yetiştirme konusunda daha yüksek düzeyde bir başarı yakalamak için veriye dayalı karar verme yolunu kullanmasını gerektirmektedir. Bu yol için akredite olmak isteyen kurum, seçilen iyileştirme yoluna odaklanmak üzere bir standart, bileşen, enine kesit temaları ve/veya standartların bir kombinasyonunu seçmektedir. Kurum, bunun için çalışmalarındaki verilere dayanarak bir odak alanı seçimi yapmakta ve neden bu seçimi yaptığına dair mantıklı bir açıklama sağlamaktadır. Son olarak, dönüşüm girişimi yolu ise akredite olmak isteyen kurumların 2013 CAEP Standartlarının tümünü nasıl karşıladıklarını göstermelerini gerektirmektedir. Ek olarak, kurum, öğretmen yetiştirme ile ilgili etkili uygulamalar konusunda alanı bilgilendiren resmi bir araştırma çalışması sunmalıdır (CAEP, 2013).

CAEP (2020a) verilerine göre, CAEP akreditasyonu almak isteyen kurum ilk olarak, CAEP tarafından istenen bilgilerin girildiği başvuru formlarını doldurduktan sonra, kurum akreditasyon sürecine hemen başlamaya veya alternatif olarak beş yıllık bir süre boyunca incelemeye hazırlanmak için hazır olduklarını belirtmektedir. İlk defa akreditasyon almak isteyen kurumlar, CAEP'in web sitesinde bulunan Faz I ve Faz II başvurularını tamamlamak durumundadır. CAEP akreditasyonu almak isteyen kurumlar çeşitli uzmanlık alanlarında okul liderleri, psikologları, okuma uzmanları, 
kütüphaneciler ve diğer okul çalışanları için var olan daha ileri düzey programları hakkında yapılan hazırlığın içeriğini ve etkinliğini incelemek için kullanılan uzmanlık lisans program alanı incelemesini tamamlamalıdır. Ayrıca kurumlar, sekiz yıllık önlem için ortak verileri bir araya getiren raporları her yıl sunmalıdırlar. Bu önlemler, öğrencinin öğrenmesi, öğretmenin etkinliği, işverenlerin ve mezunların memnuniyeti ile mezuniyet, lisans, istihdam ve öğrenci kredisi faiz oranları gibi belirli çıktılar üzerindeki etkisini göstermektedir. Bu veriler akreditasyon ziyaretleri arasındaki sürelerde kurumların CAEP 2013 standartlarını karşılama düzeyi hakkında CAEP' e bilgi vermektedir (CAEP, 2013).

Özet sorgu yolunu seçenler için CAEP, kurumun saha ziyareti için hazır olup olmadığına karar vermek için bir inceleme yapmaktadır (CAEP, 2013). Kurumlar kendi çalışma raporlarını gönderdikten sonra, CAEP bu kurumların seçtikleri yol ile ilgili kurumlar hakkında biçimlendirici bir inceleme yapmaktadır. Seçilmiş iyileştirme ve dönüşüm girişimi yolundan birini seçen kurumlar için ise CAEP, inceleme yapmak üzere bir ziyaretçi ekibi görevlendirmektedir. Bu ekip, kurumların CAEP standartlarını karşılamak için kullandıkları kanıtların kalitesini ve derinliğini incelemektedir.

CAEP (2013) verilerine göre, biçimlendirici incelemelerden sonra, ekip; kanıtları gözden geçirmek, verileri doğrulamak ve pedagojik içerikleri (örneğin, ders planları, öğrenci çalışma örnekleri, videolar) incelemek için iki ve/veya üç günlük bir saha ziyareti gerçekleştirmektedir. Ziyaret sırasında ekip kurum liderleri, öğretim elemanları, mentor öğretmenler, öğretmen adayları, öğrenciler, K-12 yöneticileri ve diğer ilgili paydaşlarla görüşmeler yapmaktadır. Mülakatlar, akreditasyon sürecinin kritik bir parçasıdır ve ziyaretçi ekibinin her bir standardın kanıtını araştırmasına, değerlendirmesine, yorumlamasına ve son olarak yeterliliğine karar verilmesinde yardımcı olmaktadır. Saha ziyaretinin sonunda, ziyaretçi ekibi, kanıtların doğruluğu ve kalitesi, doğrulanan ve doğrulanamayan durumlar/uygulamalar, metodolojiler ve kurumun güçlü yönleri ve eksiklikleri hakkındaki analizini özetleyen bir ön sözlü raporu kuruma sunmaktadır. Ziyaretçi ekibi, kanıtların artıları ve/veya eksiklikleri dâhil olmak üzere, her standardı ne ölçüde desteklediğini belirlemektedir. Ziyaretçi ekibi, standardın karşılanıp karşılanmadığı sonucuna varmamaktadır. Her bir standart için kanıtların eksiksizliği, kalitesi ve gücünün değerlendirmesini içeren ve iyileştirmeler için alanlar tahsis eden yazılı bir rapor sunmaktadır (CAEP, 2013).

CAEP Akreditasyon Kurulu (2013), saha ziyaretinin sonuçlarını değerlendirmek ve akreditasyon alma durumu ile ilgili öneride bulunmak için oluşturduğu inceleme panellerden bir diğeri de ortak gözden geçirme paneli olup; bu panel üyeleri ziyaretçi ekibi tarafindan sunulan rapor için toplanmakta ve akreditasyon sürecinde kurumun sağladığ kanıtların kalitesinde tutarlılık sağlamak için verileri kontrol etmektedir. Ortak gözden geçirme paneli, Akreditasyon Konseyine öneri sunmaktadır ve sonrasında da konsey resmi akreditasyon kararını vermektedir. CAEP daha sonra programa veya fakülteye kararını yazılı olarak bildirmektedir (CAEP, 2013).

Öğretmen yetiştirme programları için akreditasyon süreci, eyaletler, üniversiteler, akreditasyon kuruluşları ve diğer paydaşlar arasında bir ortaklık ile gerçekleşmektedir (CAEP, 2013). CAEP, yeni sürecini bu hayati ilişkilerin üzerine kurmuş, tüm paydaşlar için önemli rolleri koruyarak daha da geliştirmiştir. ABD'de pek çok eyalet, süreçlerini CAEP standartlarına göre uyarlamış ve birçoğu program incelemelerini ulusal standartlara göre düzenlemiştir. Programların onay durumu hakkında karar vermek için eyaletler CAEP ile ortaklık anlaşmaları yapmaktadır ve bu sayı her geçen gün artmaktadır. CAEP (2013), mezunların K-12 öğrenci öğrenmesi üzerinde ölçülebilir bir etkiye sahip olması açısından "sınıfa hazır" olmalarını sağlamak ve adaylara öğretmen lisansı vermeden önce adayların ilerlemesini izlemek için sıkı, yüksek kaliteli sistemler yerleştirme noktasında üniversitelerin sorumlu olduğunu belirtmektedir. Ayrıca, üniversiteler, CAEP standartlarını sağlayan kanıtların güvenilirliği ve bu kanıtların yorumlarının geçerliliğinden de sorumludur (CAEP, 2013). CAEP, öğretmen yetiştirme programlarının kanıtlara odaklanmış bir yaklaşım benimsemelerini, akreditasyon değerlendirmesi için çok miktarda veri göndermelerini değil, belirli standartlara veya 
bileşenlere etiketli verilerle kendi akreditasyon alma süreçlerini hazırlamak için seçili kanıtları birleştirmelerini gerektirmektedir (CAEP, 2013).

CAEP (2013), tüm değerlendirmeler için hem öğretmen adayları hem de K-12 öğrencileri için kaliteli eğitime yatırım yapan paydaşları bir araya getiren bir akran değerlendirme sistemi kullanmaktadır. CAEP'in (2013) akran değerlendirme sistemine katılan paydaşlar arasında öğretmenler, müdürler, politikacılar, konu alan uzmanları, halk temsilcileri ve diğer kişiler yer almaktadır. CAEP (2013), farklı uzmanlığa sahip bu hakemleri yürürlükteki tüm standartlar, politikalar ve uygulamalar hakkında eğitmektedir. Hakemler, kanıtları analiz etmekte ve kanıtların güçlü ve zayıf yönlerini belirlemektedir. Ek olarak, hakemler programın etkinliği hakkında ve CAEP (2013) standartlarını sağlaması konusunda geri bildirim vermek için akredite olmak isteyen kurumun sağladığı kanıtları kullanmaktadırlar. Hakemler ayrıca, bu kurumların kendi çalışmalarında teknoloji ve çeşitlilik temalarını yeterince ele alıp almadıklarını da incelemektedirler (CAEP, 2013).

\section{CAEP'in Standartları ve Başvuru Şartları}

2013’te CAEP, akreditasyon sürecini daha titiz ve sonuç odaklı hale getirmek için yeni standartlar ortaya koymuştur. Bu yeni standartlarla, öğretmen yetiştiren programlara öğrenci kabulü için gerekli asgari kriterler belirlenmiş ve ayrıca bu programlardan mezun öğretmenlerin öğrenci başarısı üzerindeki etkilerinin gösterilmesi zorunlu kılınmıştır (Heafner, McIntryre \& Spooner, 2014). CAEP'in (2013) standartları ve bileşenleri iki prensip üzerine kurulmuştur: Akredite olmak isteyen programın mezunlarının yeterli ve sağlam bir eğitimci olduğuna dair güçlü kanıtlar ve o programın akademik personelinin, kanıt kültürü oluşturma ve bunu programın kalitesini korumak ve artırmak için kullanma kapasitesine sahip olduğuna dair güçlü kanttlar bulunmalıdır. CAEP'in akreditasyon için oluşturduğu beş standart bu ilkelere dayanmaktadır ve bu standartların sağlandığını gösteren kanıtlar, akreditasyon sürecinin bel kemiğini oluşturmaktadır (CAEP, 2013).

Standart 1. Alan ve Pedagoji Bilgisi: Program, adayların kendi disiplinlerinin kritik kavram ve ilkelerini derinlemesine anlamalarını ve adayların programı tamamladıklarında kendi disiplinlerine özgü uygulamaları, tüm öğrencilerin öğrenmelerini, üniversiteye giriş ve kariyer hazırlığı standartlarına ulaşabilme doğrultusunda kullanmalarını sağlamaktadır.

Standart 2. Klinik Ortaklıklar ve Uygulama (Öğretmenlik Uygulamaları): Program, etkili bir şekilde işleyen ortaklıklar ve öğretmenlik uygulamalarını (staj), öğretmen hazırlama sürecinin merkezine almalıdır. Böylece öğretmen adayları, tüm K-12 öğrencilerinin öğrenmesi ve gelişimi üzerinde olumlu bir etki olması için gerekli bilgi, beceri ve mesleki deneyimleri kazanmaktadır.

Standart 3. Adayların Kalitesi, Programa Kabul Edilmesi ve Seçilmesi: Program, öğretmen adaylarının programa kabulünden, program süresince aldıkları derslerden ve öğretmenlik uygulamalarından ve hatta adayların mezun olup diploma veya sertifikalarını almaya hak kazandıklarının karar verilmesine kadar geçen süre zarfinda sürekli olarak adayların kalitesi ve yeterliğinden sorumludur. Öğretmen adaylarının kalitesinin geliştirilmesi, programın tüm aşamalarında ve tüm program boyunca programın hedefi olmalıdır.

Standart 4. Programın Etkisi: Program, mezunlarının K-12 öğrencilerinin öğrenmeleri ve gelişimi, sınıf içindeki eğitimi ve okullar üzerindeki etkisi ile bu mezunların mezun oldukları programın etkililiği ile ilgili memnuniyetlerini ortaya koymaktadır.

Standart 5. Program Kalite Güvencesi ve Sürekli İyileştirme: Program, çoklu ölçümlerden elde edilen geçerli verilerden oluşan bir kalite güvence sistemini sürdürmektedir.

Akreditasyon sürecindeki programlar, yukarıda ifade edilen beş standardı belirlenen kriterler göstergesinde asgari düzeyde sağlamak zorundadır (CAEP, 2013). Programlar, bu standartları nasıl sağladığına dair güçlü kanıtlar ortaya koymalıdır. Değerlendirme testleri, projeler, ödevler, gözlem raporları, öğrencilerin programa kabul edilmesiyle ilgili belgeler, rubrikler, anketler vb. gibi birçok 
geçerliği ve güvenirliği kanıtlanmış ölçme araçları ve bu araçlardan elde edilen veriler ortaya konulmalidır (CAEP, 2013).

\section{CAEP ve Teknoloji Entegrasyonu}

CAEP (2013), akreditasyon almak isteyen programlar için yapacağı çalışmalar kapsamında özellikle çeşitlilik ve teknoloji temalarını ele almalarına çok önem vermektedir. Bu iki tema CAEP standartlarında şu şekilde vurgulanmaktadır.

Çeşitlilik, birden fazla bakış açısının dâhil edilmesi, kültürel farklılıklara saygı ve bu farklılıkların getirdiği ihtiyaçlara cevap verebilme ve öğretmen adaylarının referans çerçevelerini anlama olarak tanımlanmaktadır (CAEP, 2013). Bu çeşitliliğin vurgulandığı standartlar şu şekildedir. Birinci standartta, tüm K-12 öğrencilerinin üniversiteye giriş şartlarını sağlayabilmeleri ve kariyer hazırlığını tamamlayabilmeleri için, bu öğrencilere öğretmenlik yapacak öğretmen adaylarının gerekli beceri ve çabayı göstermeleri gerektiği vurgulanmaktadır (CAEP, 2013). İkinci standartta öğretmen adaylarını, her tip öğrenciyle çalışabilmeye hazırlayan öğretmenlik uygulaması eğitimlerinin olması gerektiği vurgulanmaktadır (CAEP, 2013). Üçüncü standartta da programların, daha yetenekli ve farklı altyapılardan gelen aday havuzundan öğrenci alabilmek için çaba göstermesi gerektiği ifade edilmektedir (CAEP, 2013).

Teknoloji kullanımı da CAEP (2013) standartlarında önemli bir yere sahiptir. Öğrencilerin teknolojik uygulamalarla öğrenme deneyimlerinin artırılması ve yine öğretimin etkinliğini artırmak, öğretimi geliştirmek ve ölçme ve değerlendirme verilerini yönetmek için teknolojinin eğitime dâhil edilmesi CAEP tarafından önem verilen bir husustur (CAEP, 2013). Teknoloji kullanımıyla ilgili kriterler üç standartta şöyle vurgulanmaktadır: Standart göstergelerinden birincisi programların, öğretmen adaylarının öğrencilerinin ilgisini çekmek, öğrenmeyi geliştirmek ve meslek pratiği yapmak için öğrenme deneyimleri tasarlarken, uygularken ve değerlendirirken teknoloji standartlarını modellemelerini ve uygulamalarını sağlamaları gerektiğidir (CAEP, 2013). İkinci standartta da teknoloji ile geliştirilmiş öğrenme firsatları, uygun teknoloji tabanlı uygulamalar ve teknoloji tabanlı işbirlikleri olması gerektiği vurgulanmaktadır (CAEP, 2013). Üçüncü standartta ise öğretmen adaylarının teknolojiyi tüm öğrenme alanlarına entegre etmesi gerektiği belirtilmektedir (CAEP, 2013).

Öyle ki, CAEP (2013) teknoloji entegrasyonunun öğrenme süreçlerine hizmet ettiğini ve öğrenmeyi zenginleştirdiğini ortaya koymaktadır. Bir öğretimin gerçekleştirilmesinde kullanılan teknolojinin öğrenme süreçlerini zenginleştirdiği düşüncesinden yola çıkılarak, etkili bir teknoloji entegrasyonunda öğretim içeriğinin teknoloji olmadan etkili bir şekilde gerçekleştirilememesi esası söz konusudur (CAEP, 2013). Buna göre, dersin öğretim elemanı öğretim içeriğini öğrenenler ile buluşturduğu zaman, teknoloji öğrenme süreçlerine etkili ve başarılı bir şekilde entegre edilmiş ise, öğretim sürecinin teknolojiden bağımsız bir şekilde gerçekleştirilmesinin mümkün olmamas1 gerekmektedir (CAEP, 2013). Johnson ve Maddux, (2006) teknoloji entegrasyon modellerine ilişkin görüşünü "o teknoloji olmadan dersin anlatılmasının mümkün olmaması" olarak ifade etmektedir.

Bunun yanı sıra teknoloji entegrasyonunun çok ciddi bir şekilde meydan okuduğu "engeller" söz konusudur. Alanyazında yöneticilerden (Muilenburg \& Berge, 2005), öğretmenlerden (Çakıroğlu, 2013) ve bireysel inanç ve tutumlardan kaynaklanan (Ertmer, 1999) teknoloji engellerine rastlamak mümkündür. Bununla birlikte teknolojik altyapı gibi problemlerden kaynaklı engellerin de okul düzeyinde karşılaş1lan engeller olduğu belirtilmektedir (Ertmer, 1999). Alanyazında yapılan çalışmada, öğretmen düzeyindeki engellerin teknolojiye erişim, kurumsal ve teknik destek, zaman ve maddi konuların dışsal engeller; öğretmenlerin bilgisayarlar ile ilgili sahip oldukları inanç ve tutumlar, sınıf içi uygulamalar ve değişime isteksizliği içsel engeller olarak ifade edilmektedir (Ertmer, 1999). Başka bir çalışmada da öğretmenlerin teknoloji entegrasyonu için belirlemiş oldukları ortak problemlerin vizyon, erişim, zaman, değerlendirme ve mesleki gelişim olduğu ifade edilmektedir (Franklin vd., 2001). Snoeyink ve Ertmer (2001) ise çalışmasında ekipman eksikliği, 
ekipmanın güvenilmezliği, teknik destek eksikliği ve diğer kaynaklarla ilgili konuları birinci engeller, kurum kültürü gibi okul düzeyindeki faktörler ile öğretmenlik ve teknoloji ile ilgili inanç, tutumlar ve değişime açıklık gibi öğretmen düzeyindeki engelleri de ikinci engeller olarak ele almaktadır. Son olarak, Hamutoğlu ve Başarmak (2020) teknoloji engellerini içsel ve dışsal engeller olarak ortaya koymakta olup; kalite sürecinde yükseköğretimde amaçlara ve hedeflere ulaşmada yaşanan teknolojik engellere ilişkin görüşlerin de dışsal (altyapı sorunları, kaynak kısıtlılığı, vizyon) ve içsel teknoloji engelleri (bireysel eksiklikler, inanç) ile ilgili olduğu tespit edilmiştir (Hamutoğlu vd., 2020). Ayrıca yapılan çalışmada çevrimiçi öğrenme ortamlarının tasarımlarının ve etkili bir teknoloji entegrasyonu sürecinin kalite süreçlerine yansıdığı da belirtilmektedir (Hamutoğlu \& Başarmak, 2020).

Söz konusu alanyazında ele alınan engeller teknoloji entegrasyonu açısından büyük bir handikap oluşturmaktadır. Öyle ki teknolojinin öğretim sürecinin içerisinde etkili ve başarılı bir şekilde entegre edilmesinde gerek öğretmenden gerekse altyapı, vizyon, eğitim vb. yönetim ve yönetimsel süreçlerden kaynaklanan problemlerin minimize edilmesi gerekmektedir. Gerçekleştirilen bu minimizasyon teknoloji entegrasyonunu olumlu yönde destekleyecek bir alt yapıyı oluştururken kalite süreçlerine de şüphesiz ki katkı sağlayacaktır. Kurumların kalite arayışlarında gerçekleştirdikleri faaliyetlerdeki standardizasyonu sağlama anlayışı, teknoloji engellerinin ortadan kaldırılması ile beklenen sonuca ulaşmayı kolaylaştıracaktır.

\section{Dünyada ABD dışında CAEP tarafından Akredite Edilmiş Kurumlar, Akreditasyon Süreci ve Eğitim Açısından Önemi}

CAEP'in web sayfasında yer alan akredite olmuş kurumların listelendiği verilere göre, dünyada şu anda ABD dışında CAEP tarafindan akredite olmuş üç üniversite vardır: Umman'da Sultan Qaboos Üniversitesi, Katar'da Qatar Üniversitesi ve Birleşik Arap Emirlikleri'nde Zayed Üniversitesi'dir. Bu çalışmada CAEP tarafindan akredite olmuş üniversiteler ile iletişime geçilerek teknoloji entegrasyonu açısından da zengin bilgilere ulaşıldığı gerekçesiyle sadece Qatar Üniversitesi'ne ait akreditasyon süreci hakkında bilgi verilecek ve eğitim açısından önemine değinilecektir.

\section{Qatar Üniversitesi’nin Akreditasyon Süreci}

Qatar Üniversitesindeki eğitim fakültesi, ülkenin kurulan ilk enstitüsü olup, bugün de ülkenin öğretmen yetiştiren tek kurumu olarak hizmet etmeye devam etmektedir. Literatür, özellikle yükseköğretimde değişimin, çok yavaş ve sanc1lı olduğunu söylemesine rağmen, Katar'da eğitim sektöründeki değişikliklerin hem hızlı hem de sistemik olduğu görülmüştür. Üniversitenin dekanı Hissa Sadiq ve ögretim üyesi Nancy Allen'ın akreditasyon sürecini anlattıkları bir makale yayınlamışlardır (Sadiq \& Allen, 2016). Buna göre, Katar'da eğitimdeki hızlı değişimin gerçekleşebilmesinin sebeplerinden birinin, bu ülkede anayasal monarşi olduğu; böylece eğitim ile ilgili politik kararların daha çabuk verilmesi olduğu düşüncesi ifade edilmektedir. Bir diğer sebep olarak da Katar'ın özel kültürel bağlamı görülmüştür. Katar bir İslam devleti olup, İslamın değerleri ve normları eğitim sisteminin içine de yerleşmiştir. Ulusal bir üniversite olan Qatar Üniversitesi de bu değer ve normların üniversitedeki tüm programların tüm unsurlarına yansıtılması konusunda titiz davranmıştır. Araştırmalar, eğitim programlarında başarılı değişikliklerin yapılması, bu değişikliklerin programın bulunduğu yerel kültür ve yerel önceliklerle uyumlu olmasına bağlı olduğunu göstermektedir (Altbach, 2003; Eckel \& Kezar, 2003; Parsons \& Fidler, 2004).

Katar'da gerçekleșen eğitim reformu, 2001'de Katar'daki K-12 düzeyindeki okullardan mezun öğrencilerin küresel düzeyde rekabet edecek yeterlikte olmadığının fark edilmesi temeline dayanmaktadır (Sadiq \& Allen, 2016). Bunun üzerine 2003'te ülkenin eğitim sisteminde kapsamlı ve geniş tabanlı bir reform yapılmasına en üst hükümet düzeyinde karar verilmiş olup; kar amac1 gütmeyen bir araştırma organizasyonu tarafından mevcut eğitim sisteminin değerlendirilmesi ve ülkenin değişen ihtiyaçlarına cevap verecek bir sistemin kurulması için öneri sunulması gerekliliği 
ortaya konulmuştur (Vukelich vd., 2010). Organizasyon, Katar okullarını ve milli eğitim sistemini dünya standartlarında bir eğitim sistemine dönüştürmek için sistematik bir reform önermiştir (Vukelich ve diğerleri, 2010). Bu reform hareketini özerklik, çeşitlilik, hesap verilebilirlik ve sistem içinde seçim konularına odaklanan tamamen yeni bir çerçeve oluşturmaktadır (Sadiq \& Allen, 2016; Vukelich vd., 2010). Plan, Katar'ın milli eğitim sistemine bağlı tüm okulları kapsamakta olup; bu okulları öğretim programı standartlarını takip eden, bu standartlara dayalı değerlendirme yapan, öğrenci merkezli öğretime dayanan, öğretim dili olarak İngilizce kullanan, daha kapsamlı mesleki gelişim üzerine odaklanan bağımsız (charter) okullara dönüştürmeyi içermektedir. Bu okulların gözetimi için de yeni bir denetim kurulu oluşturulmuş olup; K-12 düzeyinde gerçekleşen eğitim reformunun ihtiyaçlarını karşılayacak öğretmen yetiştirme programlarının yeniden inşa edilebilmesi için mevcut tüm eğitim fakültesi programları reformdan geçmiştir (Sadiq \& Allen, 2016). Aşamalı olarak, üniversite bu çerçevede reformun ilkelerini (öğrenci merkezli bir öğretim, kapsamlı paydaş katılımı vb.) temel alarak gerekli değişiklikleri yapmış olup; bu ilkeler doğrultusunda yüksek ahlaki standartlara dayalı ve kalkınma için küresel ortaklıklar üzerinde önemli rol oynayabilecek adil ve özenli bir toplumun gelişimine odaklanmıştır. Daha sonra da aşamalı olarak eğitim programları tekrar aktif olarak çalışmaya başlamış olup, bu süreçte uluslararası üniversitelerle de işbirliği yapılmıştır (Sadiq \& Allen, 2016). Buradan anlaş1lyyor ki Qatar Üniversitesi her ne kadar İslami değerlerin hakim olduğu kendi kültürel bağlamında reformları gerçekleştirmiş olsa da bu reformları aslında uluslararasılaşma bağlamında evrensel ilke ve değerler ile gerçekleştirmek amaçlanmaktadır.

Çağdaş yükseköğretimde değişim için en güçlü yollardan biri uluslararasılaşmadır (Taylor, 2004). Caruana (2008) uluslararasılaştırmayı küreselleşmenin yol açtığı değişikliklere bir cevap olarak tanımlamaktadır. Bu, özellikle Katar için de geçerlidir. Katar 2030 Ulusal vizyonunda Katar'ın gelecekteki ekonomik başarısının bilgiye dayalı ve son derece rekabetçi yeni uluslararası düzene ayak uydurabilecek insanların artarak yetişmesine bağlı olduğu belirtilmektedir. Qatar Üniversitesi de son yıllarda mezunlarını küresel toplumun ihtiyaçlarına hazırlamayı amaçlamış ve bu doğrultuda, 2008'den bu yana tüm öğretmen yetiştirme programlarının uluslararası düzeyde tanınması ve akredite olması için arayışa girmiştir.

Qatar Üniversitesinin web sayfasındaki akreditasyon verilerine göre (Katar, 2015) Katar ilk olarak 2010'da Öğretmen Eğitiminde Kalite Güvence Merkezi'nden (Center for Quality Assurance in Teacher Education-CQATE) Öğretmen Eğitiminde Uluslararası Tanınma (International Recognition in Teacher Education- IRTE) sertifikası almak için çalışmalara başlayarak akreditasyon sürecine girmiştir. Katar'daki ilk ve tek öğretmen yetiştiren üniversite olarak, Qatar Üniversitesi, geniş bir paydaş yelpazesiyle birlikte çalışarak öz değer, inanç ve yöntemlerin ifade edilmesi için çalışmalarda bulunmuştur. Üniversite, tüm paydaşlarla işbirlikli çalışarak öğrenme ve öğretme hakkındaki mevcut inançları ve bunları destekleyen araştırmaları belirlemiştir. Daha sonra da birçok kez gözden geçirip, yenileyip geliştirdikleri kavramsal çerçeveyi ortaya koymuşlardır. Bu kavramsal çerçevede profesyonel bir öğrenme topluluğunun olmasının önemine varılmıştır. Akreditasyon yolculuğu boyunca, bu durum sadece programların ve fakültenin geliştirilmesinde değil, aynı zamanda değişikliklerin kabul edilip kurumsallaştırılması açısından da kilit rol oynamaktadır. Bu profesyonel öğrenme topluluğu şu özellikleri içermektedir:

- $\quad$ Öğrenmeye odaklanma

- Herkes için öğrenmeyi vurgulayan işbirlikçi bir kültür

- $\quad$ En iyi uygulamaları ortaya çıkarmak için kolektif araştırma

- $\quad$ Yaparak öğrenme

- Sürekli iyileştirme taahhüdü

- Sonuçlara odaklanma 
Qatar Üniversitesi, tüm akademisyenler ile birlikte program öğrenme çıktıları ve standartlarını belirlemişlerdir. Veri kullanımının ve verinin en iyi şekilde toplanabilmesinin programın gelişimi için önemli olduğu göz önünde bulundurularak, kilit görevler belirlenmiştir. Öğretim elemanları birlikte çalışarak, rubrikleri yazıp, gözden geçirip geliştirmişlerdir. Atanan kilit görevlerin sonuçları periyodik olarak gözden geçirilip, elde edilen verilere göre eylem planları oluşturulmuştur. Öğretim elemanları derslerini geliştirmek için çok çaba göstermiş, değerlendirme sürecinin doğru çalışabilmesi ve işletilebilmesi için gerekli ilkeleri, süreçleri ve becerileri öğrenmişlerdir. Ayrıca, öğretim elemanları yapılan faaliyetlerin başarısının sürdürülebilir olması ile ilgili olduğunu ve bu süreçte devamlılığın esas olduğunun önemini anlamışlardır. Akreditasyon komitesi geldiğinde, eğitim fakültesi altı standardın, beşini ilk ziyarette, diğer standardı da bir sonraki ziyarette sağlamayı başarmıştır. Ocak 2011'de CQATE'den, almış olup, NCATE akreditasyonu için hazırlıklara başlamıştır. Bu süreçte, CQATE kapanıp CAEP konseyi ile birleşmiştir (Katar, 2015).

Ülkedeki ve üniversitedeki değişiklikler eğitimi önemli ölçüde değiştirmekle beraber, eğitim fakültesi olarak, kavramsal çerçevede açıklanan değerlere sadık kalmışlardır. Bu çerçevenin içeriği şu şekilde ifade edilmektedir:

- Katar'ın tarihi, kültürü ve değerlerini onurlandırma.

- Uluslararası standartlarda pedagojik bilgi, içerik bilgisi ve eğilimleri ölçüt alarak zorlayıcı akademik programlar sağlama

- Sosyal ve eğitim problemlerinin çözümlerine katkıda bulunma

- Ulusal ve uluslararası düzeyde çeşitliliğe saygı gösterme

- İşbirliğine dayalı uygulama topluluklarını teşvik etme

- Eğitimi geliştirmek için en son teknolojileri kullanma

- Eğitimde teori ve uygulamaya katkıda bulunmak için burslar sağlama

- Yaşam boyu öğrenmeyi teşvik etme

- En yüksek mesleki etik standartları geliştirme.

Yukarıda sayılan maddeler, eğitim fakültesinin akreditasyon sürecinde daha etkili ve somut olarak gerçekleştirilmiştir. Katar Hükümeti, eğitimde mükemmelliği yakalamak ve uluslararası düzeyde rekabet edebilmek için öğretmenlerin öneminin farkında olmuştur. Akreditasyon sürecinde, yüksek standartlar ortaya konmuş ve paydaşlarla ortak çalışarak süreç başarıyla tamamlanmıştır (Sadiq \& Allen, 2016).

\section{Qatar Üniversitesi’nin Akreditasyon Sürecinde Gerçekleştirdiği Teknoloji Entegrasyonu}

Qatar Üniversitesi, CAEP'in ikinci standardını sağlamak için oluşturduğu değerlendirme sistemi içerisinde, tüm başlangıç programlarının bir öğretim teknolojisi projesini içermesini gerektirmiştir. Üniversitenin web sayfasındaki (Katar, 2015) verilere göre, şunlar söylenebilir: Başlangıç programlarındaki tüm öğretmen adaylarının, öğretmenlik uygulaması deneyimleri sırasında, öğrenme ve öğretme için teknolojiyi kullandıklarını, teknolojiyi kullanmasının zorunlu bir bileşen olduğu, bir ders planlama ve bu dersi uygulayarak göstermeleri zorunlu hale getirilmiştir. Öğretimdeki teknoloji kullanımını değerlendirmek için oluşturulan rubriklerde, öğretmenin öğrenmeyi daha motive edici, özgün ve etkili hale getirmek için çeşitli teknolojileri yaratıcı bir şekilde kullanması, kullanılan teknolojinin etkileşimli, ilgi çekici ve dersin hedeflerini desteklemesi hedeflenmiştir. Teknoloji, öğrencilere sağlanan öğrenme firsatı için önemli olarak görülmüştür. Öğrenme için teknoloji kullanımını değerlendirirken de K-12 öğrencilerinin bilgiyi oluşturmalarını, araştırmalarını ve/veya analiz etmelerini sağlayan teknolojiler kullanıyor olmaları beklenmiştir. 
Ayrıca öğrencilerin teknolojiyi kullanımı, onların öz-yönelimli öğrenen olmalarını sağlamaları da büyük önem arz etmektedir. Yardımcı teknolojilerin kullanımı açısından öğretmen adaylarının özel öğrencilerin öğrenme fırsatlarını geliştirmek için oluşturulmuş teknolojilerin yaratıcı şekilde kullanımlarını tanımlayabilmeleri de beklenmiştir. Teknoloji kullanımı, K-12 öğrencilerinin yaratıcılığını ve üst düzey düşünmelerini teşvik etmelidir. Bunun için de öğretmen adaylarının teknoloji kullanımının yansımaları, öğrencinin öğrenmesine odaklanmalı; öğretmen adayları teknolojinin öğrenmeyi nasıl etkilediğini, geliştirdiğini veya kısıtladığını açık ve derinlemesine bir bakış açısıyla tanımlamalı; planlama ve sınıf yönetimi için teknolojiyi etkin bir şekilde kullanmalıdır. Ayrıca eğiticiler bilgi toplamak, düzenlemek, paylaşmak ve oluşturmak için teknolojiyi kullanma konusunda öğrencilerin aktif rol almasını sağlamalı ve her öğrenciye öğrenme firsatı sağlamak için yardımcı ve artırıcı teknolojileri bilmeli ve bu teknolojileri etkili bir şekilde kullanmalıdır (Vukelich vd., 2010).

Öğretim elemanları da teknolojinin öğretime entegrasyonunu ciddi olarak benimsemişlerdir. Teknoloji kullanımında, öğretmen adaylarına model olmakta olup, tüm öğretim elemanları düzenli olarak powerpoint sunumları hazırlamakta, akıllı tahtaları, diğer görsel-işitsel cihazları, kablosuz interneti, Blackboard V9.1 ${ }^{\text {TM }}$ ve TaskStream TM öğrenme yönetim sistemlerini öğretim sürecini etkili bir şekilde sunma, değerlendirme ve geri bildirimler için kullanmaktadırlar (Vukelich vd., 2010). Özetle teknoloji uygun ödev ve projelerle tüm programların içine entegre edilmiştir. Örneğin, öğretmen adaylarının yazılım değerlendirmeleri, mikro öğretim, teknolojiyi entegre ettikleri ders planları, dijital kaynakların değerlendirilmesi, veri toplanması ve analizi ile teknolojinin getirdiği sorunlar gibi birçok konuda çalışmalar yapmaları gerekmiştir (Vukelich vd., 2010). Bunun dışında öğretmen adayları, öğretim üyelerini tüm derslerde her dönem değerlendirmek için kampüs çapında bir çevrimiçi değerlendirme sistemi kullanmaktadır. Eğitim fakültesi ayrıca öğretim üyelerinin mesleki gelişimine atölye çalışmaları ve yüz yüze danışmanlık şeklinde destek sağlamıştır. Bu desteklerden biri de eğitim teknolojileri ve Qatar Üniversitesinin elektronik sistemleri kullanma konusundadır.

Yine Sadiq ve Allen (2016)‘e göre Katar, her seviyede hükümete bağlı sistemik bir reformun ortasında olup, kampüste ve işbirlikli okullarda adayların standartları yakalaması amacıyla olağanüstü olanaklara erişimlerini sağlamıştır. Tesisler, öğretim üyelerinin ve danışmanların (mentor) teknolojinin öğretim amacıyla kullanılmasını ve modellenmesini sağlamak amaciyla öğretim üyelerine tahsis edilmiştir. Öğretim üyeleri birçok kaynă̆ın yanı sıra, projelerinde kullanmak üzere iPad ve dijital kameraları kütüphaneden tedarik edebilmektedir. Öğrenme ve öğretme deneyimlerini geliştirmede, öğretim üyeleri ve adaylar için "ders kaydetme" sisteminin kullanıldığı bir laboratuvar kurulmuştur. Bu laboratuvar kablosuz mikrofonları ve kayıt cihazını kullanan Blackboard V.9.1. ile entegre çalışan yeni bir öğretim ve sınıf tesisidir. Kaydedilen dersler Blackboard üzerinden her dersten sonra erişime açılmıştır. Dersler kalıcı olarak yayınlanmış böylece öğrencilerin Qatar Üniversitesinde öğrenimleri boyunca aldıkları eğitimleri herhangi bir yerde veya zamanda tekrar izleme firsatına sahip olmaları sağlanmıştır.

Qatar Üniversitesi web sayfası verilerine göre, Qatar Üniversitesi, tüm öğrencilere kampüs e-postası, İnternet, ağ kaynakları, kapsamlı elektronik kütüphane veri tabanları ve bir e-kayıt sistemine erişim sağlamıştır. Tüm programlardaki tüm öğretim üyeleri ve öğretmen adayları, eFolio'larını geliştirmek ve değerlendirme sistemine kilit ödevlerini yüklemek için TaskStream TM kullanmaktadır (Vukelich vd., 2010). Üniversite, teknoloji hizmetlerine kablosuz erişimi destekleyecek şekilde sürekli güncellemeler sağlamıştır. Bilişim Teknolojileri servisi, başarılı bir şekilde birçok gigabit omurgası ve ultra yüksek hızlı İnternet erişimini kullanıma açmış, bağlantı ve ağ hizmetleriyle kampüste binlerce dizüstü bilgisayar, masaüstü bilgisayar ve bilgisayar laboratuvarı hizmete sunmuştur. Eğitim fakültesi ayrıca kendi eğitim teknolojileri programındaki öğretim üyeleri aracılığıyla çevrimiçi ve hibrid derslerin geliştirilmesini desteklemiştir. Ayrıca, farklı içerik alanlarında öğretmen adaylarının öğrenmesini desteklemek ve adaylara öğretim teknolojilerini 
tanıtmak için kullanılan kapsamlı bir sanal ortama (I-Cube) erişim de sağlanmıştır. Bununla birlikte, fakültede, öğretim üyelerinin ve öğretmen adaylarının yüksek kaliteli video ve ses teknolojisi kullanarak kampüs dışından konuk konuşmacıların konferans vermesini sağlayan bir video konferans tesisi de kurulmuştur. Ayrıca fakülte öğretim elemanlarının, öğretimde, bilişim teknolojilerinin kullanımını modellemesine ve aday öğrenme deneyimlerini arttırmasına olanak sağlayan son model teknoloji ve tesislerle donatılmıştır.

\section{Ülkemiz Öğretmen Yetiştirme Kurumlarının Akreditasyonunun Önemi}

Eğitim fakültelerinin uluslararasılaşma ve dünya standartlarında kaliteyi yakalama açısından akredite olması önemlidir. $\mathrm{Bu}$ standartlara ulaşmak için yapılacak sürekli iyileştirmeler ve sürdürülebilir yenilikler eğitim fakültelerinde erişilmek istenen çıktıyı yakalamada gerekli reformları hayata geçirmesine neden olabilir. Eğitim fakültelerinin kalitesinin artması daha nitelikli, günümüz teknoloji dünyasını anlayan, yorumlayan ve değerlendiren dijital okuryazarlık becerileri yüksek; gelişen teknolojiyi uygun pedagojik yöntemler ile öğrenme-öğretme süreçlerine entegre edebilen, 21. yüzyılın gerektirdiği diğer beceriler ile donatılmış öğretmenlerin ve dolaylı olarak da öğrencilerin yetişmesini sağlaması açısından oldukça önemlidir.

Ülkemizde üniversitelerin öğretmen yetiştirme programlarında 2017 y1lına kadar gerçekleştirilen değişimlerde henüz akreditasyon ve kalite sürecini benimseyen bir yaklaşımın ele alınmadığı görülmektedir. Oysaki 1990'l1 yıllarda öğretmen yetiştirme programlarının akreditasyonuna yönelik başlatılan çalışmalarda, Milli Eğitim Bakanlığı (MEB) ile Yükseköğretim Kurulu (YÖK) arasında gerekli işbirliği ve koordinasyonu sağlamak üzere kurulan Öğretmen Yetiştirme Millî Komitesi'nin (ÖYMK) eğitim fakültelerinde niteliksel bir standartlaşmayı sağlamak adına öğretmen yetiştirmede kalite güvencesi için akreditasyon sistemi kurmanın gerekli olduğu görüşü benimsenmiştir (EPDAD, 2020a). Türkiye'de öğretmen eğitimi akreditasyon sisteminin altyapısının oluşturulması adına gerçekleştirilen faaliyetler Öğretmen Eğitiminde Standartlar ve Akreditasyon (YÖK,1999) yayınında raporlanmış olup, geliştirme süreci tamamlanan akreditasyon sistemi uzun soluklu bir aşama kaydetmeden ve ulusal akreditasyon sistemine dönüşmeden askıya alınmıştır. Bununla birlikte resmi kuruluş sürecini 14 Haziran 2012 tarihinde tamamlayan Öğretmenlik Eğitim Programları Değerlendirme ve Akreditasyon Derneği'nin (EPDAD) amac1 öğretmen yetiştiren kurumlarda kalite güvencesi ve akreditasyona yönelik olumlu tutum geliştirmek, farkındalık oluşturmak, yönetici ve öğretim elemanlarını temel bilgi ve becerilerle donatmaktır (URL 1, 2020). Bir akreditasyon kuruluşu olarak EPDAD, Türkiye Cumhuriyeti Yükseköğretim Kalite Güvencesi Mevzuatına tabi olup, bu mevzuat uyarınca kurulan Yükseköğretim Kalite Kurulu (YÖKAK) tarafından yetkilendirilerek gerçekleştirdiği program değerlendirme ve akreditasyon faaliyetleri, kalite güvencesi bilinci geliştirme ve kurumsallaştırma çalışmaları düzenli olarak izlenir (EPDAD, 2020b). "Öğretmen yetiştirmede mükemmeliyet" vizyonuna ve niteliği garanti altına alan ve örgün eğitimde öğrenci ögrenmesini güçlendirmek amacıyla sürekli gelişimi destekleyen kanıt temelli akreditasyon yoluyla ögretmen yetiştirmede mükemmeliyete ulaşma" misyonuna katk1 sağlamak adına EPDAD (1) Öğretmen yetiştirmede kaliteyi artırmak, (2) Sürekli gelişimi desteklemek, (3) Araştırma ve inovasyonu geliştirmek, (4) Akreditasyonun değerini artırmak, (5) Model bir akredite edici kuruluş olmak ve (6) Model bir ögrenme organizasyonu olmak stratejik hedeflerine ulaşmayı amaçlamaktadır (EPDAD, 2020c). EPDAD Türkiye'de YÖKAK tarafindan tescil edilen ulusal akreditasyon kuruluşlardan birisidir (EPDAD, 2020d). EPDAD öğretmen eğitimi standartları, "nitelikli öğretmenler yetiştirilmesini sağlamak için yürütülen bir lisans programının taşıması gereken asgari özellikler" olarak tanımlanmakta olup, öğretmen eğitimi akreditasyon sistemi sırasıyla başlangıç, süreç ve ürün standartları olmak üzere üç grup standart üzerine oturmaktadır ve bu standart grupları öğretim, personel, öğrenciler, işbirliği, fiziksel altyapı, yönetim ve kalite güvencesi adlarını taşıyan yedi standart alanı içerisinde yer almaktadır (EPDAD, 2020e). 


\section{Sonuç, Öneri ve Sinırlılıklar}

$\mathrm{Bu}$ çalışmada öğretmen eğitiminin kalitesini artırmada ve yeni ilişkiler geliştirmede uluslararası düzeyde kalite çalışmalarını gerçekleştiren bir kurum olan Eğitimci Yetiştirme Akreditasyon Konseyi'nin (Council for the Accreditation of Educator Preparation- CAEP) öğretmen ve öğretmen eğitimcisi yetiştirmede sahip olduğu güçlü ve zengin akreditasyon geçmişi hakkında bilgi verilmesi amaçlanmıştır. Bu amaç kapsamında çalışmada CAEP'in amacı, akreditasyon süreci, standartları ve başvuru süreci ile teknoloji entegrasyonuna ilişkin bilgiler sunulmaktadır. Ayrıca çalışmada Dünya'da, ABD dışında CAEP tarafından akredite edilmiş kurumlar ile bu kurumların eğitim açısından önemine ilişkin bilgiler de sunulmuştur. Son olarak ülkemiz öğretmen yetiştirme kurumlarının akreditasyonunun önemine ilişkin bilgiler de çalışmada yer almaktadır.

Öğretmen eğitiminde niteliğin sağlanması ve sürdürülebilirliğine yönelik yapılan araştırmalar ve öneriler her geçen gün daha da artsa da "niteliğin" öğretmen eğitimine nasıl yansıtılacağına yönelik tartışmalar devam etmektedir (Şişman, 2017). Uluslararası akreditasyon, kısmen daha büyük bir kalite güvencesi konusu ile ilgili olduğu için önemli bir konudur (Altbach, 2003). Buna göre, elde edilen bilgiler 1şığında öğretmen eğitiminde uluslararası akreditasyonun oldukça önemli olduğu söylenebilir. Çünkü öğretmen eğitimi yeni nesil öğrenen bireylere 21. yüzyıl becerilerinin kazandırılmasında oldukça önemlidir. Amerikan Öğretmen Eğitim Kurumları Birliği (The American Association of Colleges for Teacher Education [AACTE]) ve 21. Yüzyıl Becerileri Ortaklığı (Partnership for 21st Century Skills [P21]) tarafından hazırlanan raporda, öğretmen adaylarının, derinlemesine anlama, akademik konu alanında uzmanlaşma ve 21. yüzyıl becerilerine yönelik olarak bir programın nasıl geliştirilip kullanılacağına ilişkin yeterliliğe sahip olmaları gerektiği; ancak bunun ilave bir ders veya ders saati eklemenin çok ötesinde bir yaklaşım gerektirdiği vurgulanmaktadır (Greenhill, 2010). Bu yaklaşımın etkili bir akreditasyon süreci ile gerçekleştirilebileceğine inanılmaktadır. Midraj ve Harold'a (2016) göre, akreditasyon, öğretmen yetiştirme programlarının, öğretmenleri ve diğer okul personelini hazırlamak için önemli uluslararası mesleki standartları yakaladığının kanıtıdır. Bu noktadan hareketle uluslararasılaşma sürecinde öğretmen yetiştirme programları uygulamalarının mesleki standartlar ile uyumluluğunun kanıtlanması oldukça önemlidir. Her ne kadar ülkelerin ulusal akreditasyon kurumlarınca programlarının kalitesini kanıta dayalı olarak sunma girişimleri söz konusu olsa da bu girişimlerin küresel düzeyde ele alınması önemlidir. Küreselleşmenin yükseköğretimde kitlesel talebi oluşturma (Altbach, 2005) tanımından yola çıkarak ögretmen yetiştirmede yapılan uygulamaların uluslararası düzeye taşınması gerekmektedir. $\mathrm{Bu}$ yüzden akademik kurumların öğretmen yetiştirme programlarında küresel düzeyde rekabet edebilmesini sağlamada uluslararası düzeyde akreditasyon gerçekleştirilmesi önemlidir.

Çalışmada CAEP tarafından ABD dışında akredite olan kurumlara bakıldığında genelde Arap ülkelerinin olduğu dikkat çekmektedir. Zira, CAEP dünyada öğretmen yetiştirme programlarının akreditasyonu konusunda uluslararası tanınırlığı ve güvenirliği oldukça yüksek bir kurumdur. Her ne kadar çalışmada elde edilen sonuçlarda, CAEP tarafindan akredite edilmiş öğretmen yetiştirme programlarının sayıca fazla olması ve Arap ülkeleri dışındaki farklı ülkelerin de öğretmen yetiştirme programlarının akredite olması beklenmekte iken; elde edilen bu sonucun şaşırtıcı olduğunu söylemek gerekir. Belirtilen durumun nedenleri bu çalışmanın amaçları arasında yer almasa da elde edilen sonuç üzerinde sosyo-ekonomik nedenler, akreditasyon sürecinin uzun ve maliyetli olması ile farklı ulusal ve uluslararası akreditasyon kurumlarının da varlığının etkili olabileceği düşünülmektedir. Ayrıca, farklı ülkelerin de CAEP'e akreditasyon almak için başvurduğu ancak sürecin henüz tamamlanmadığı da çalışma sonuçları doğrultusunda öngörülmektedir (CAEP, 2020b). CAEP tarafindan akredite edilmiş bir kurum olan Qatar Üniversitesi her ne kadar antropolojik olarak Türkiye'ye direkt model olmasa da Türkiye'de eğitim fakültelerinin bir süre öğrenci almayı bırakıp, bu sırada MEB ve ilgili diğer kurumlar ile sıkı bir işbirliği içerisinde olmasının önemli olduğu düşünülmektedir. Ayrıca Qatar Üniversitesi'nin yönetim anlayışı monarşik 
bir düzen esasına dayanıp, bu durum eğitimde hızlı bir reform gerçekleştirebilmelerinin gerekçesi olarak görülse bile; bu düzenin ülkemiz Türkiye Cumhuriyeti'nin yönetim anlayışı ve politikaları açısından kabul edilemez olduğu söylenebilir. Katar örneğini, Türkiye'ye vermek veya Türkiye'deki üniversiteleri, Katar'daki bir üniversite mantığıyla akredite etme modellemesi en azından Türkiye'nin demokratik çoğulcu ve cumhuriyet rejimi ile yönetilen bir ülke olması nedeniyle çok uygun bir örnek olmasa da öğretmen eğitiminde kalite konusundaki uygulamaları ülkemiz kültürel bağlamı ve değerleri gözetilerek örnek alınması söz konusu olabilir. Zira, yerel kültürel bağlam gözetilmeksizin uluslararası düzeyde bir akreditasyonun gerçekleştirilmesinin tehlikeli etkileri olabilmektedir (Altbach, 2003). Nitekim, Altbach (2005) uluslararasılaşmayı yeni dünyadan en iyi şekilde faydalanmayı firsat bilerek ülkelerin ve akademik sistemlerin politikalar geliştirmesine ve uygulamasına olanak veren dinamikleri içerisinde barındırdığını ifade etmektedir. Buna karşın, Romanowski (2020) ve Romanowski ve Alkhateeb (2020) küreselleşme çatısı altında gerçekleştirilen akreditasyon uygulamalarını eğitim bağlamında gerçekleştirilen yeni sömürgecilik tipi olarak ve McDonald's metaforu kullanarak eleştirmektir. Bu bağlamda, öğretmen eğitiminde kalite söz konusu olduğunda yapılacak düzenlemelerde istenilen çıktıları elde etme hususu göz önünde bulundurularak; ülkelerde yapılan düzenlemeler, ülkemiz demokratik ve çoğulcu yönetim anlayışı ve düzeni esasında gerçekleştirilerek uygulamaya geçirilmesi önerilmektedir. Bu doğrultuda yapılan uygulamaların aynı şekilde olduğu gibi değil de ülkemiz Türkiye Cumhuriyeti'nin demokratik ilkeleri ve yönetim anlayışı çerçevesi temelinde uyarlanarak ele alınması gerekmektedir.

Türkiye'de öğretmen yetiştirme programlarında zaman zaman köklü değişime veya dönüşüme gidildiği görülmektedir (YÖK, 1998; YÖK, 2006; YÖK, 2018). Öğretmen yetiştiren kurumların üniversiteye devredilmesinin üzerinden geçen on beş yıldan sonra, YÖK/Dünya Bankası Milli Eğitimi Geliştirme Projesi kapsamında; Kasım 1997-Ocak 1998 tarihleri arasında eğitim fakültelerinin yeniden yapılandırılmasıyla ilgili olarak, Erzurum, Trabzon, İstanbul, İzmir ve Adana'da birer günlük bölgesel bilgilendirme toplantıları düzenlenmiş ve 1998-1999 öğretim yılında Mesleki Eğitim Fakülteleri ile Teknik Eğitim Fakülteleri dışındaki eğitim fakültelerinde yeniden bir yapılanmaya gidilmiştir (MEB, 1998, s.85). Bununla birlikte, 2006 y1lında Eğitim Fakülteleri Araştırma raporu (YÖK, 2006) ve Yükseköğretim Stratejisi Raporu (YÖK, 2007a) öğretmen eğitiminde bir nitelik sorunu olduğunu ortaya koymakta olup yeniden bir değişime gitmiştir. Bu düzenleme ile eğitim fakülteleri lisans programlarındaki alan ve alan eğitimi derslerinin \%50-60, öğretmenlik meslek bilgisi derslerinin \%25-30 ve genel kültür derslerinin \%15-20 oranları çerçevesinde belirlenerek ve bazı derslerin adlarında, sürelerinde ve kredilerinde değişiklikler yapılmıştır (YÖK, 2007b). Son olarak, 2017 yılında "Yeni Öğretmen Yetiştirme Lisans Programları" nın tanıtımı yapılarak yirmi beş öğretmenlik lisans programının içeriği MEB tarafından geliştirilen Öğretmenlik Mesleği Genel Yeterlikleri ve Öğretmen Strateji Belgesi (2017-2023) (MEB, 2020) göz önünde bulundurularak güncellenmiştir. Ayrıca mevcut programlar yeni Bologna süreci ile de uyumlu hale getirilerek eğitim/eğitim bilimleri fakülteleri arasında ders kredileri yönünden mevcut sorunlar giderilmiş olup, AKTS yönünden fakülteler arasında standart sağlanmış ve programlarda $\% 25$ oranında da seçmeli derslere yer verilmiştir (www.memurlar.net, 2018). Bu programlardaki değişim ulusal boyutta gerçekleştirilen çalışmaları uluslararası platformlara taşımamak ile birlikte, kalkınma planlarında yapılması planlanan uygulamaların sonuçlarının henüz görülmeden köklü veya yüzeysel değişim ve dönüşüme gittiği görülmektedir. Değişim ve dönüşüm, gelişen ve değişen paradigmalar ışığında gerçekleşmelidir ve mevcut program altyapısını geliştirme ve destekleme misyonu ile uygulamaya konulmalıdır. Bu durumda, öğretmen yetiştirme programlarının kalitesini değerlendirme ve sürdürülebilirliğini uluslararası standartları gözeterek sağlama konusunda akreditasyon çalışmalarının artarak devam etmesi önerilmektedir.

Ayrıca, ulusal düzeyde çalışmalarını gerçekleştiren akreditasyon kurumlarının bu noktada MEB ve diğer kurumlarla ortaklık içinde kalite standartlarını Türkiye'nin kendi kültürel bağlamı (üniversite, eğitim kurumları, MEB, diğer paydaşlar vb.) içinde oluşturup gerekli kalite standartlarına 
ulaşmak için sistemi yeniden yapılandırması ve daha genel bir akreditasyon sistemi oluşturması önerilebilir. Ayrıca tüm öğretim elemanlarının da katkıda bulunduğu bir akreditasyon sürecine girilmelidir. Sürdürülebilir hedeflerin başarısının paydaşlarla sürekli işbirliği içerisinde olması ile ilişkili olduğu söylenebilir. Aksi durumda geçici çözüm önerileri ile elde edilen sonuçların uluslararası düzeye taşınması oldukça zor görünmektedir. Bu noktada eğitim fakültelerinde değer yaratma vizyonu ve katılımcı-işbirlikli misyonu çerçevesinde gerçekleştirilen farkındalık çalışmaları ile öğretmen yetiştirme programlarının uluslararası düzeyde rekabet edebilecek konuma gelebilmesi mümkündür. Öğretmen eğitiminde istenilen kaliteye ulaşmada Türkiye'deki eğitim fakülteleri kendi kültürel bağlamı içinde kendi yerel çeşitliliklerini de göz önünde bulundurarak ve günümüz öğretim teknolojilerini de başarılı bir şekilde entegre ederek akreditasyon sürecine girmelidirler. Çünkü içinde bulunduğumuz dijital çağda, gerçekleştirilmesi beklenen etkili ve verimli eğitsel uygulamaların müfredat ile bütünleşmiş bir teknoloji entegrasyonu ile mümkün olabileceği düşünülmektedir. $\mathrm{Bu}$ durumda öğretmen yetiştiren kurumların müfredatlarında yer alan dersleri teknoloji ile zenginleştirilmiş bir şekilde revize ederek öğrenciler ile buluşturması önerilmektedir. $\mathrm{Bu}$ dijital dönüşüm ile birlikte kurumların gelecekte de varlıklarını uluslararası düzeyde sürdürebilmeleri ihtimali ulaşılabilir hedefler arasında yer alabilir. Uzun vadede de eğitim fakültelerinin akredite olması MEB'in öğretmen kalitesini artırmak adına talep ettiği bir şart olarak ortaya çıkabilir ve böylece akredite olmak ihtiyaç haline de gelebilir. Ayrıca uluslararası akreditasyon alarak, mezunların uluslararası düzeyde istihdamı sağlanabilir.

Bu çalışma CAEP'in öğretmen eğitimi konusundaki akreditasyonuna, ABD dışındaki bir kurumun CAEP tarafindan akredite edilmesi sürecine ve teknoloji entegrasyonuna yönelik bilgiler ile sınırlıdır. Bu sınırlılıktan yola çıkarak, gelecek çalışmalarda Türkiye'nin öğretmen yetiştirme sistemi, CAEP ile birlikte diğer önemli uluslararası işbirlikleri ile de (örneğin Avrupa Birliği-AB ülkelerinin bağlı olduğu) ele alınarak yapılan uygulamaların neler olduğuna ilişkin bilgiler araştırılabilir. 18 Ağustos 2020 tarihinde Türkiye Yükseköğretim Kurulu'nun “eğitim fakültelerindeki öğretmenlik programlarının ders, müfredat ve kredilerine YÖK değil yükseköğretim kurumları karar verecek. Eğitim fakülteleriyle ilgili bu önemli düzenlememiz üniversitelerimize çok geniş bir hareket serbestisi tanımakta olup bu 'yetki devri', eğitim fakülteleri ve öğretmenlik programlarıyla ilgili tarihi bir karar olarak değerlendirilebilecek niteliktedir." şeklindeki açıklamaları ile eğitim fakültelerine önemli bir yetki devrini gerçekleştirmiştir (www.memurlar.net, 2020). Bu gelişmenin umut verici olduğunu söylemek ile birlikte öğretmen yetiştiren yükseköğretim kurumları farklılaşma stratejileri belirleyerek ihtiyaç duyulan ve küresel düzeyde yeterlikleri tanınan programlar düzenleyebileceği ve 21. yüzy1l becerilerini de işe koşarak değişen ve dönüşen şartlara uygun, uyarlanabilir becerilere odaklanan kurumsal öğrenme çıktıları üzerinde çalışılabilir. Bu noktada gelecek çalışmalarda CAEP tarafından akredite edilmiş ve ABD eyaletlerinde yer alan öğretmen yetiştirme alanında dünyaca bilinen çeşitli üniversitelerin programları da incelenebilir. Ayrıca bu ülkelerde teknoloji entegrasyonunun öğretmen yetiştirme programları ile nasıl bütünleştirildiğine ilişkin uygulamaların da takip edilmesi ile, ülkemiz yükseköğretim kurumlarının ehliyet ve kabiliyetleri doğrultusunda gerekli adaptasyon çalışmaları yapılarak kurumların teknolojiyi etkili bir şekilde kullanmalarını mümkün kılan çalışmalara odaklanılabilir. Son olarak, AB'nin de öğretmen yetiştirme alanında akreditasyon sağlayan kurumlarının çalışmaları incelenebilir. Bu noktada AB'nin bağlı bulunduğu, öğretmen yetiştirme akreditasyon sistemlerinin de CAEP ile rekabet edebilir özelliklere sahip olduğu düşünülmektedir. 


\section{Kaynakça}

Altbach, P. (2003). American accreditation of foreign universities: Colonialism in action. International Higher Education, (32), 5-7.

Altbach, P. G. (2005). Globalization and the university: Myths and realities in an unequal world. The NEA 2005 Almanac of Higher Education. http://www.nea.org/assets/ img/PubAlmanac/ALM_05_06.pdf

Altbach, P. G. \& Knight, J. (2007). The Internationalization of Higher Education: Motivations and Realities. Journal of Studies in International Education, 11(3-4), 290-305. https://doi.org/10.1177/1028315307303542

Bakioğlu, A. (2017). Karşılaştırmalı eğitim politikalar, göstergeler, bağlamlar. Eğitim Yayınevi.

CAEP (2013). CAEP Accreditation Standards. http://caepnet.org/ /media/Files/caep/standards/ caep-2013-accreditation-standards.pdf

CAEP (2020a). Council for the accreditation of educator preparation. http://caepnet.org/

CAEP (2020b). Accredited provider \& recognized search. http://caepnet.org/providersearch?state $=J O \&$ provider $=\&$ tab $=$ provider\#provresults

Caruana, V. (2008). Internationalization of higher education: Globalisation discourse, institutional strategy and curriculum design. In E. O'Doherty (Ed.), The Fourth Education in a Changing Environment, (pp.1-18). Informing Science Press.

Çakıroğlu, Ü. (2013). Öğretim teknolojilerinin öğrenme ortamlarına entegrasyonu. In K. Çağıltay \& Y. Göktaş, Y. (Eds.), Öğretim teknolojilerinin temelleri: teoriler, araştırmalar, eğilimler (pp. 413-430). Pegem Akademi.

Çiçek, D. (2016). Yeni iletişim teknolojilerinin haber tüketim eğilimleri üzerinde oynadı̆̆ rol [Yayımlanmış yüksek lisans tezi]. İstanbul Ticaret Üniversitesi, Sosyal Bilimler Enstitüsü, Medya ve İletişim Bilimleri.

Eckel, P. D. \& Kezar, A. J. (2003). Taking the reins: Institutional transformation in higher education. Greenwood Publishing Group.

EPDAD (2020a). Öğretmenlik eğitim programları değerlendirme ve akreditasyon derneği (EPDAD) Tarihçe. https://epdad.org.tr/icerik/tarihce

EPDAD (2020b). Öğretmenlik eğitim programları değerlendirme ve akreditasyon derneği (EPDAD) Resmi Statü ve Yetki. https://epdad.org.tr/icerik/resmi-statu-ve-yetki

EPDAD (2020c). Öğretmenlik eğitim programları değerlendirme ve akreditasyon derneği (EPDAD) Vizyon, Misyon ve Stratejik Hedefler. https://epdad.org.tr/icerik/vizyon,-misyon-vestratejik-hedefler

EPDAD (2020d). Öğretmenlik eğitim programları değerlendirme ve akreditasyon derneği (EPDAD) Sistem ve EPDAD. https://epdad.org.tr/icerik/sistem-ve-epdad

EPDAD (2020e). Öğretmenlik eğitim programları değerlendirme ve akreditasyon derneği (EPDAD) EPDAD Öğretmen Eğitimi Standartları. https://epdad.org.tr/icerik/epdad-ogretmen-egitimistandartlari

Erkutlu, H. \& Eryiğit, S. (2001). Uluslararasılaşma süreci. Gazi Üniversitesi İktisadi ve İdari Bilimler Fakültesi Dergisi, 3(3), 149-164.

Ertmer, P. A. (1999). Addressing first-and second-order barriers to change: Strategies for technology integration. Educational Technology Research and Development, 47(4), 47-61. 
European Commission, (2013). Supporting Teacher Educators: For Better Learning Outcomes. http://ec.europa.eu/dgs/education_culture/repository/education/policy/school/doc/supportteacher-educators_en.pdf

Federation of Teachers (2016). https://www.aft.org/periodical/american-educator/2016

Franklin, T., Turner, S., Kariuki, M. \& Duran, M. (2001). Mentoring overcomes barriers to technology integration. Journal of Computing in Teacher Education, 18(1), 26-31.

Greenhill, V. (2010). 21st century knowledge and skills in educator preparation. AACTE Partnership for 21st Century Skills.

Hamutoğlu, N. B. \& Basarmak, U. (2020). External and internal barriers in technology integration: A structural regression analysis. Journal of Information Technology Education: Research, 19, 017-040. https://doi.org/10.28945/4497

Hamutoğlu, N. B., Başarmak, U., Sezen-Gültekin, G. \& Elmas, M. (2020). The Views of The Quality Ambassadors on Quality Management in Higher Education and the Technological Barriers Encountered. Cukurova University Faculty of Education Journal, 49(1). https://dx.doi.org/10.14812/cufej.596963

Hamutoğlu, N. B. \& Başarmak, U. (2020). Çevrimiçi Öğrenme: Farklı bakış açıları (1.baskı) (Ed(ler) Kılıç-Çakmak, E. \& Karataş, S.). Çevrimiçi öğrenme ortamlarında ögretim tasarımı. Pegem Akademi, 195-225.

Heafner, T., McIntyre, E. \& Spooner, M. (2014). The CAEP standards and research on educator preparation programs: Linking clinical partnerships with program impact. Peabody Journal of Education, 89(4), 516-532. https://doi.org/10.1080/0161956X.2014.938998

Johnson, L. \& Maddux, C. D. (2006). Information technology: Four conditions critical to integration in education. Educational Technology, 46(5), 14-19.

MEB (1998). Milli Eğitim: Cumhuriyet'in 75. Yllında Gelişmeler ve Hedefler. Milli Eğitim Basımevi.

MEB (2020). Öğretmenlik mesleği genel yeterlikleri ve öğretmen strateji belgesi. http://oygm.meb.gov.tr/meb_iys_dosyalar/2017_06/09140719_Strateji_Belgesi_Resmi_Ga zete_sonrasY_ilan.pdf

Midraj, S. \& Harold, B. (2016). Quality Assurance in Teacher Education: The Role of Accreditation. In Michelli, N.M., Dada, R., Eldridge, D., Tamim, R.M., Karp, K. (Eds.), Teacher quality and teacher education quality: Accreditation from a global perspective. (pp. 61-80). Routledge.

Muilenburg, L. Y. \& Berge, Z. L. (2005). Student barriers to online learning: A factor analytic study. Distance Education, 26(1), 29-48.

Organisation for Economic Co-operation and Development (OECD), (2016). https://www.oecdilibrary.org/docserver/eag-2016en.pdf?expires $=1598960893 \&$ id $=$ id\&accname $=$ oid $014567 \&$ checksum $=9$ FD55934F98FF0 B2BB14D65D85163747

Parsons, C. \& Fidler, B. (2004). De-internationalisation in higher education: the case of UK plc. Higher Education Review 36(3), 13-22.

Romanowski, M. H. (2020). CAEP Accreditation: Educational Neocolonialism and Non-US Teacher Education Programs. Higher Education Policy, 1-19. https://doi.org/10.1057/s41307-02000205-X 
Romanowski, M. H. \& Alkhateeb, H. (2020). The McDonaldization of CAEP accreditation and teacher education programs abroad. Teaching and Teacher Education, 90, 103028. https://doi.org/10.1057/s41307-020-00205-x

Qatar University College of Education (2015). NCATE. http://www.qu.edu.qa/education/ about/Accreditation/ncate-2015

Sadiq, H. \& Allen, N. (2016). Accreditation for the college of education, Qatar University. In Michelli, N.M., Dada, R., Eldridge, D., Tamim, R.M., Karp, K. (Eds.), Teacher quality and teacher education quality: Accreditation from a global perspective. (pp.129-141). Routledge.

Şişman, G. T. (2017). Öğretmen yetiştirme lisans programları ders içeriklerinde "eğitim programı" kavram1. Elementary Education Online, 16(3). https://doi.org/ 10.17051/ilkonline.2017.330259

Snoeyink, R. \& Ertmer, P. (2001) Thrust into technology: how veteran teachers respond. $J$ Educa Technol Syst 30(1), 85-111.

Taylor, J. (2004). Toward a strategy for internationalization: Lessons and practice from four universities. Journal of Studies in International Education 2(8), 149-171.

Vukelich, C., Bracy, P., Haidar, A., Konopak, B. \& Lilly, S., (2010). Center for quality assurance in teacher education. International recognition of teacher education. Recognition visit to Qatar University.https://www.qu.edu.qa/static_file/qu/colleges/education/accreditation/document s/1.5.d_reports_of_other_associations.pdf

YÖK (1998). “Cumhuriyet döneminde ögretmen yetiştirmenin tarihi gelişimi” eğitim fakülteleri ögretmen yetiştirme programlarının yeniden düzenlenmesi ile ilgili rapor. Ankara.

YÖK (1999). Türkiye'de öğretmen eğitiminde akreditasyon ve standartlar. YÖK/Dünya Bankas1 Milli Eğitimi Geliştirme Projesi Hizmet Öncesi Öğretmen Eğitimi. Ankara. https://www.yok.gov.tr/Documents/Yayinlar/Yayinlarimiz/turkiyede_ogretmen_egitiminde _standartlar_ve_akreditasyon.pdf

YÖK (2006). Eğitim fakülteleri araştırmast. Yüksek Öğretim Kurumu Yayını.

YÖK (2007a). Türkiye’nin yüksek öğretim stratejisi. Yüksek Öğretim Kurumu Yayını.

YÖK (2007b). Eğitim fakültesi öğretmen yetiştirme lisans programları. http://www.yok.gov.tr/web/guest/icerik//journal_content/56_INSTANCE_rEHF8BIsfYRx/ $10279 / 49875$

YÖK (2018). Eğitim fakültelerinde uygulanacak yeni programlar hakkında açıklama. https://www.yok.gov.tr/Documents/Kurumsal/egitim_ogretim_dairesi/OgretmenYetistirme/1- aciklama_programlar.pdf

YÖK'ten eğitim fakültelerine önemli yetki devri. (2020, Ağustos). www.memurlar.net. https://www.memurlar.net/haber/922101/

25 öğretmenlik lisans programı güncellendi. www.memurlar.net (2018, Mayıs). https://www.memurlar.net/haber/ 749268/25-ogretmenlik-lisans-programi-guncellendi.html 